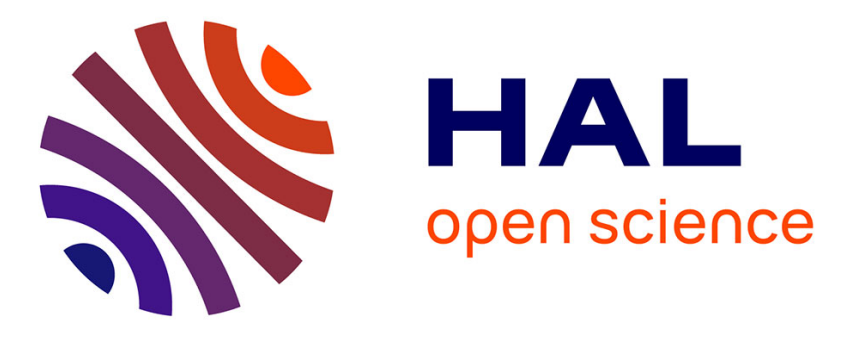

\title{
An occupant-based energy consumption model for user-focused design of residential buildings
}

Toufic Zaraket, Bernard Yannou, Yann Leroy, Stéphanie Minel, Emilie

Chapotot

\section{- To cite this version:}

Toufic Zaraket, Bernard Yannou, Yann Leroy, Stéphanie Minel, Emilie Chapotot. An occupantbased energy consumption model for user-focused design of residential buildings. Journal of Mechanical Design, 2015, special issue on "User Needs and Preferences in Design Engineering", pp.1-11. 10.1115/1.4030202 . hal-01152335

\section{HAL Id: hal-01152335 \\ https://hal.science/hal-01152335}

Submitted on 15 May 2015

HAL is a multi-disciplinary open access archive for the deposit and dissemination of scientific research documents, whether they are published or not. The documents may come from teaching and research institutions in France or abroad, or from public or private research centers.
L'archive ouverte pluridisciplinaire HAL, est destinée au dépôt et à la diffusion de documents scientifiques de niveau recherche, publiés ou non, émanant des établissements d'enseignement et de recherche français ou étrangers, des laboratoires publics ou privés. 
Zaraket T., Yannou B., Leray Y., Minel S., Chapotot E. (2015) 'An occupant-based energy consumption model far user-facused design of residential buildings', Jaurnal of Mechanical Design, no. special issue on "User Needs and Preferences in Design Engineering", dai: 10.1115/1.4030202

\title{
An occupant-based energy consumption model for user-focused design of residential buildings
}

\author{
Authors: Toufic Zaraket ${ }^{1,{ }^{*}}$, Bernard Yannou ${ }^{1}$, Yann Leroy ${ }^{1}$, Stephanie Minel ${ }^{2}$, Emilie Chapotot ${ }^{2}$ \\ ${ }^{1}$ Laboratoire Genie Industriel, Ecole Centrale Paris, \\ Grande Voie des Vignes, 92290 Chatenay- Malabry, France \\ 2 ESTIA, Technopole Izarbel \\ Bidart, France \\ * Corresponding author
}

Toufic Zaraket (Corresponding author)

Ecole Centrale Paris, Laboratoire Genie Industriel

Grande Voie des Vignes, 92290 Châtenay Malabry, France

Phone : +33 659457741

Fax : +33141131272

Email : toufic.zaraket@ecp.fr

\begin{abstract}
Occupants' behavior exerts a significant influence on the energy performance of residential buildings. Industrial energy simulation tools often account for occupants' as monolithic elements with standard averaged energy consumption profiles. Predictions yielded by these tools can thus deviate dramatically from reality. This paper proposes an activity-based model for forecasting energy and water consumption of households, and discusses how such an occupant-focused model may integrate a user-focused design of residential buildings. A literature review is first presented followed by a brief recall of the proposed modeling methodology and a sample of simulation results. The possible integration of the proposed model into the design and energy management processes of residential buildings is then demonstrated through a number of use cases.
\end{abstract}

Keywords: Energy modeling, energy management, residential building, performance contract, households, occupant profile, user needs, consumption variability, domestic activity, human behavior, user-focused design. 
Zaraket T., Yannau B., Leray Y., Minel S., Chapatot E. (2015) 'An accupant-based energy consumption madel far user-facused design of residential buildings', Jaurnal of Mechanical Design, no. special issue on "User Needs and Preferences in Design Engineering", dai: 10.1115/1.4030202

\section{INTRODUCTION}

The building stock accounts for between 16 and 50 percent of national energy consumption worldwide [1$3]$. Governments around the world are thus rolling out energy directives, national regulations and energyefficiency labels that set minimum requirements for buildings' performance [4], and promote the construction of green buildings [5]. Buildings' stakeholders have thereby started dealing with buildings as products-with-services rather than just simple products. Services may for instance include energy monitoring or equipments' maintenance during a building's use-phase. Moreover, new market expectations such as the 'energy performance contracts' have started to emerge in a number of countries [6]. Such services and offers require thus a better control of performance's variability during a building's lifecycle. Consequently, a better comprehension and consideration of the key determinants of energy performance has become essential for the design and marketing processes of buildings.

Occupant behavior is a substantial source of uncertainty in energy modeling since. It can impact energy consumption by as much as $100 \%$ for a given dwelling [2,7-14]. Industrial energy simulation tools such as Energy Plus and eQUEST propose some simplifications regarding occupants' behavior (among other simplifications), which may lead to unrealistic energy estimates, and may eventually be one of the reasons behind high discrepancies between predicted and real energy consumption values [15-18]. Nowadays, such performance discrepancies are no longer tolerated - especially in the case of green (energy-efficient) buildings. More precise methods are therefore needed to model occupants' influence on buildings' energy performance. Such models should result in more accurate energy estimations, and hence improve building designs and marketing offers.

The authors have proposed an activity-based model of residential energy demand (SABEC ${ }^{1}$ ) in a doctoral dissertation [19]. The present paper is not intended to detail the model, but it briefly recalls the adopted modeling methodology. The main focus here is to show how a user-focused model, which accounts for occupants' energy-related needs and activities, can be used within the engineering design, energy management processes, and marketing offers of residential buildings.

A literature review is first presented followed by a brief recall of the proposed modeling methodology and a sample of simulation results. The possible integration of the proposed model into the design and energy management processes of residential buildings is then demonstrated through a number of use cases.

\section{BACKGROUND AND RELATED WORK}

\subsection{Occupants' Behaviour and Energy Use Trends in Residential Buildings}

According to Ellegård and Palm [20], energy use is embedded in most aspects of households' daily life. People use energy and water to satisfy their daily living needs and activities such as preparing food and supplying heat and light $[21,22]$. Scientific literature points out the major end-use groups of energy such as space heating, space cooling, domestic hot water, appliances and lighting [3,23,24]. This energy consumption is highly dependent on the behavior of occupants $[2,14,25]$. Past experience shows that energy usage can vary dramatically from one household to another $[12,13,27]$. This variation reflects the heterogeneity in occupants' needs and preferences. Literature confirms the presence of high correlations between household attributes on the one hand, and domestic appliances ownership levels, their energy rating, and their use patterns on the other [25,28-34]. This would explain why general assumptions about occupants' behavior imply ambiguities and inevitably lead to significant uncertainties in energy predictions. Therefore, a better modeling of occupant-related energy consumption must merge from a better understanding of their needs, preferences and usage-contexts, and, thus from a better representation of their socio- economic and demographic attributes that influence their energy consumption trends.

\footnotetext{
${ }^{1}$ SABEC : stands for Stochastic Activity Based Energy Consumption
} 
Zaraket T., Yannau B., Leray Y., Minel S., Chapatot E. (2015) 'An accupant-based energy consumption madel far user-facused design of residential buildings', Jaurnal of Mechanical Design, no. special issue on "User Needs and Preferences in Design Engineering", dai: 10.1115/1.4030202

\subsection{Existing Modelling Approaches}

Literature reveals the existence of a number of different scientific techniques for modeling energy consumption in residential buildings [11]. Some authors, such as Seryak \& Kissock [13] and Yohanis et al. [35], use real sub-metering data in order to derive representational loads (so-called "diversity profiles") of occupants energy use, and thus deduce estimates of buildings' total energy consumption. Other modeling methods are those aiming at simulating occupancy patterns and various energy-load schedules by using stochastic approaches (e.g. Monte Carlo Markov Chains) that are based on national time use surveys (TUS) [18]. Authors such as Tanimoto [36] , Richardson et al. [37,38], Widén and Wäckelgård [39], Muratori [40] and Subbiah [41] adopted such type of approaches. These modeling approaches yet still have some drawbacks. First, even though they correlate occupancy schedules to appliance usepatterns and consumption, yet to the authors' knowledge, neither of the existing approaches establishes the link between occupants' daily living needs (Maslow's pyramid) and their related energy consumption. Second, they do not generate energy demand profiles based on the activities performed in each household and more particularly by each household member. Therefore, they lack the capability to depict usesituations such as the sharing phenomena of appliances and activities (e.g. Watching TV). Third, the existing models are not exhaustive in representing household attributes (such as the income, age, etc.), where in most cases, the main variable considered for representing households is the number of occupants. Consequently, such models cannot assess energy consumption variability between different population segments and household profiles.

Based on these conclusions, we believe that a user-focused statistically-derived approach which correlates occupants' profiles (socio-economic and demographic) on the one hand, to activities, appliance ownership and use trends, and usage contexts on the other hand, can be very useful for the design process of buildings. The benefits of such a model may not be limited to energy consumption predictions, but it can go further to be used for adapting building design solutions and for energy monitoring and management during the use-phase of buildings for instance.

\section{RECALL OF THE SABEC MODEL}

SABEC model is developed in the scope of forecasting occupant-related energy consumption in residential buildings, while accounting for variability in consumption patterns due to heterogeneity in occupants' socio-economic and demographic profiles [19]. The model accounts mainly for energy consumption related to domestic activities such as watching TV, washing dishes, and doing laundry. The structure of the proposed Activity-Based Energy Consumption SABEC model is presented in Figure 1, whereas its different objects are very briefly introduced in this section. Occupants' behavior is characterized through a need-activity-action paradigm. We consider that occupants satisfy their daily living needs (e.g. house-caring) by performing a set of daily activities (e.g. washing dishes), which in turn are conducted through a set of actions (e.g. wash dishes by machine, wash dishes by hand). Exhaustive inventories of energy-use needs, activities, actions and appliances are established in accordance with existing literature and related theories (e.g. Maslow's pyramid, activity theory) [19]. An Activity-based model entails that energy consumption of a household is estimated by summing up the energy use of different activities performed (such as cooking, washing clothes, etc.). The model is of a stochastic nature due to the twofold probabilistic mapping (conditional probabilities) established between household attributes (household type, number of occupants, socio-professional category, etc.), as well as the corresponding appliance ownership rates, appliance characteristics and power ratings, and activity quantities. A household model with an exhaustive representation of occupants' attributes is proposed.

Domestic activities are classified according to their nature (shared, additive), and a quantification unit is attributed for each of them (service unit). For a given activity (a given need), the service unit is coupled with appliance's energy rating in order to estimate the resulting energy and water consumption. The 
Zaraket T., Yannau B., Leray Y., Minel S., Chapatat E. (2015) 'An occupant-based energy consumption model far user-facused design of residential buildings', Jaurnal of Mechanical Design, no. special issue on "User Needs and Preferences in Design Engineering", dai: 10.1115/I.4030202

proposed model can thus quantify energy consumption per domestic activity at the level of a specific individual or household. We highlight here that the technical and computational aspects of the model are not presented in this paper. For more details, the reader may refer to [19] and [44,45].

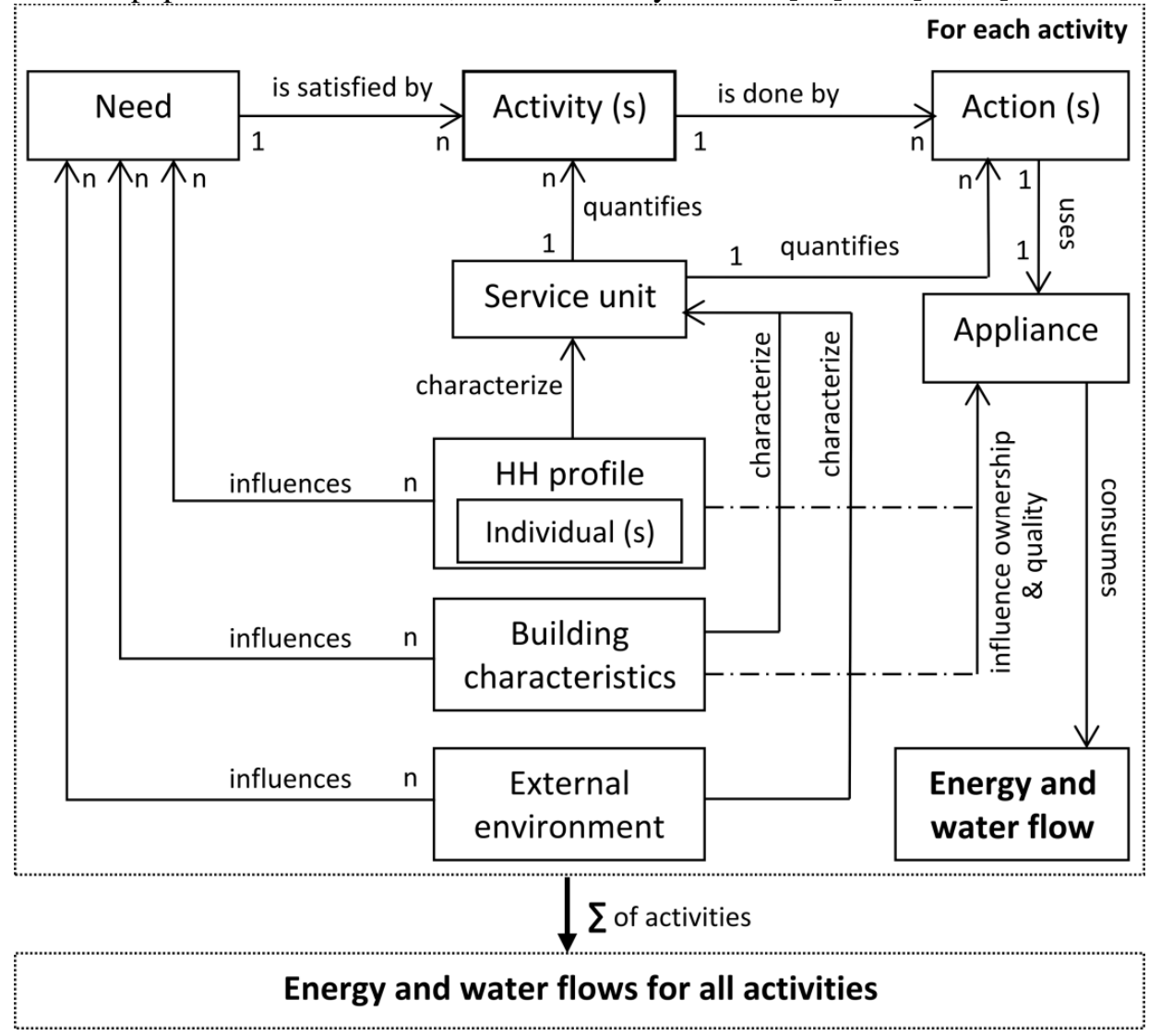

Figure 1: Architecture of SABEC model

\section{SAMPLE APPLICATIONS OF THE MODEL}

The proposed SABEC model was applied for a number of domestic activities. Only some examples of simulation results are presented here to demonstrate model's utility. A first example is illustrated through Figure 2. The cumulative distribution plot represents electricity consumption of the activity "watching TV" for a sample of 1000 randomly generated households. The plot fits into a normal distribution with an average value of $3.95 \mathrm{KWh} /$ week and a standard deviation of $2.75 \mathrm{KWh} /$ week. The variation in consumption values, which is clearly demonstrated through the distribution, reflects the heterogeneity of household profiles of the sample.

The model also permits to perform energy consumption simulations for specific profiles of households by defining constraints on their attributes. The box plot in Figure 3 shows a sample of electricity consumption results for the activity "watching TV" for four different French household clusters. Each distribution on the box plot corresponds to 10000 simulation runs. The plots show how electricity consumption may vary from one household type to another for the same activity. 
Zaraket T., Yannou B., Leray Y., Minel S., Chapatat E. (2015) 'An occupant-based energy consumption model far user-facused design of residential buildings', Jaurnal of Mechanical Design, no. special issue on "User Needs and Preferences in Design Engineering", dai: 10.1115/1.4030202

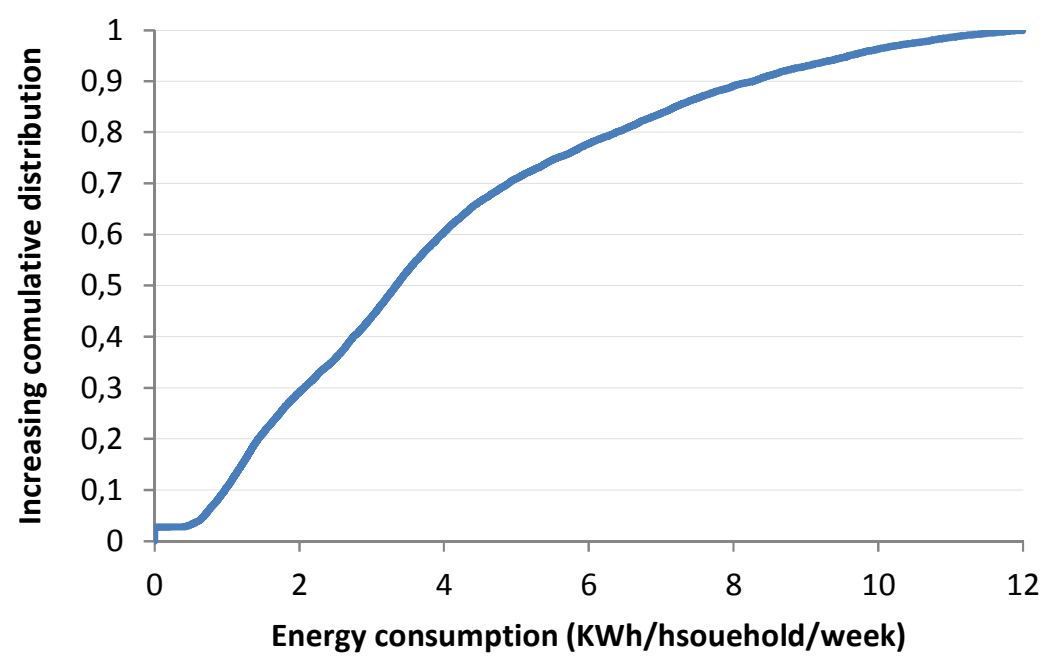

Figure 2: Cumulative distribution of electricity consumption values for the activity "Watching TV" for a sample of 1000 randomly generated households

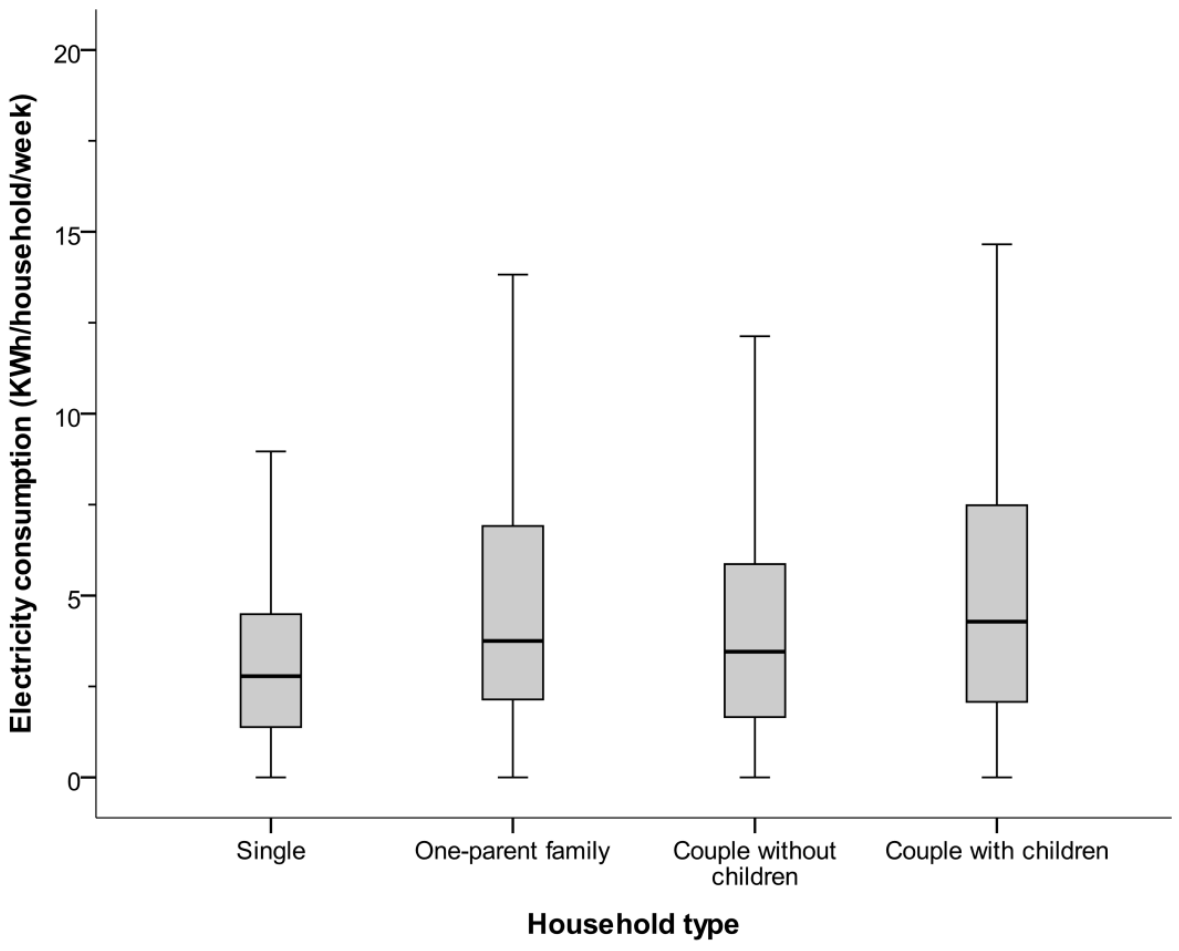

Figure 3: Simulation results of electricity consumption for the activity "Watching TV": Comparison between five household-type clusters of the French population

Another example of simulation results is given in Figure 4. The plots represent electricity consumption distributions of the activity "washing laundry". The households considered have the same household type 
Zaraket T., Yannau B., Leray Y., Minel S., Chapatat E. (2015) 'An occupant-based energy consumption model far user-facused design of residential buildings', Jaurnal of Mechanical Design, no. special issue on "User Needs and Preferences in Design Engineering", dai: 10.1115/I.4030202

and same numbers of adults and children, but different income levels. Each of the presented plots corresponds to 1000 simulation runs. The simulation samples presented in this section demonstrate how the SABEC model can be used for assessing energy consumption variability among different household clusters at the level of a domestic activity.

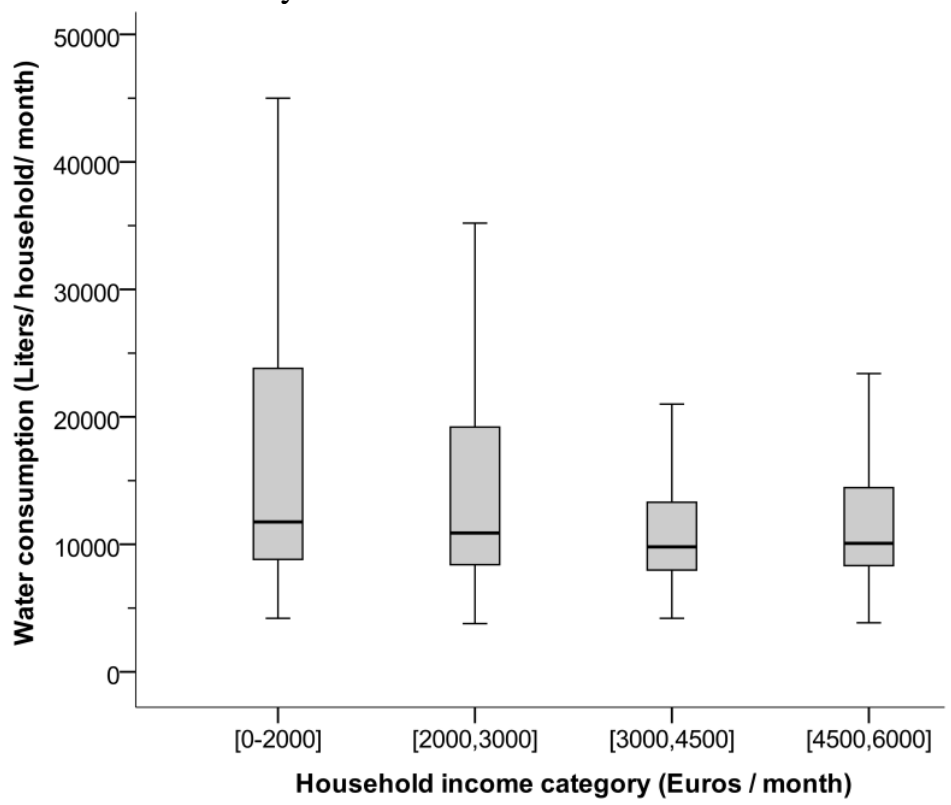

Figure 4: Simulation results of electricity consumption for the activity "Washing laundry": variability of consumption as a function of the income cluster

\section{INTEGRATION OF THE PROPOSED MODELING APPROACH INTO THE DESIGN AND MARKETING PROCESS OF RESIDENTIAL BUILDINGS}

As discussed earlier, building experts need to predict the influence of occupants on the overall performance of buildings, as early as possible in the design phase. Even though building contractors and designers do not know the exact profiles of a building's future occupants, they may still have an abstract image of those profiles. The information about future occupants are used by architects, designers, and engineering consultants to better adapt the building's design accordingly, and to better propose maintenance and energy management services during buildings' use-phase. The proposed SABEC model may thus serve in such an industrial context.

\subsection{More Accurate Forecasting Of Occupant-Related Energy Consumption}

The model presented in this paper may be used as a complementary tool to traditional energy simulators. As pointed out in the second section, industrial simulation tools are not sufficiently granular to account accurately for electricity and water consumptions yielded by domestic activities. A possible advantage of using the SABEC model would thus be to provide more accurate energy estimates at the level of domestic activities and appliances. The model would also be used to assess variability in energy consumption values between different occupant clusters. 
Zaraket T., Yannau B., Leray Y., Minel S., Chapatat E. (2015) 'An occupant-based energy consumption model far user-facused design of residential buildings', Jaurnal of Mechanical Design, no. special issue on "User Needs and Preferences in Design Engineering", dai: 10.1115/I.4030202

\subsection{Promoting Design and Construction Solutions}

Accurate energy models may enable building designers to get more precise insights about occupants' energy consumption patterns. This would help them promoting design and technical solutions that limit these consumptions by making them more independent of occupants' variability. A possible use of the model may be thus to estimate the usage durations of electro-domestic appliances, which generate 'internal heat gains', and therefore to better forecast cooling and heating loads. The model may also be used to identify major energy-consuming end-uses (activities) in order to guide some design solutions. For instance, the installation of low energy-consuming bulbs can reduce the electricity consumption for lighting, and thus limit the variability that may arise from occupants' personal lighting equipments. We have performed a case study to test a specific design alternative related to the installation of a central laundry room equipped with energy-efficient washing machines in a residential building composed of 54 dwellings of different sizes. Using SABEC model, estimations of energy and water consumption for the "washing laundry" activity are quantified for the two cases (presence and absence of such a central laundry room) and for all of the dwellings. The electricity and water consumption results for each of the 54 households are shown in Figure 5. The results revealed that savings in electricity for the whole building (54 households) can reach up to $206 \mathrm{KWh} /$ month that is a reduction of $37 \%$, where savings in water are about 14139 liters/month that is a reduction of $31 \%$ (Table).

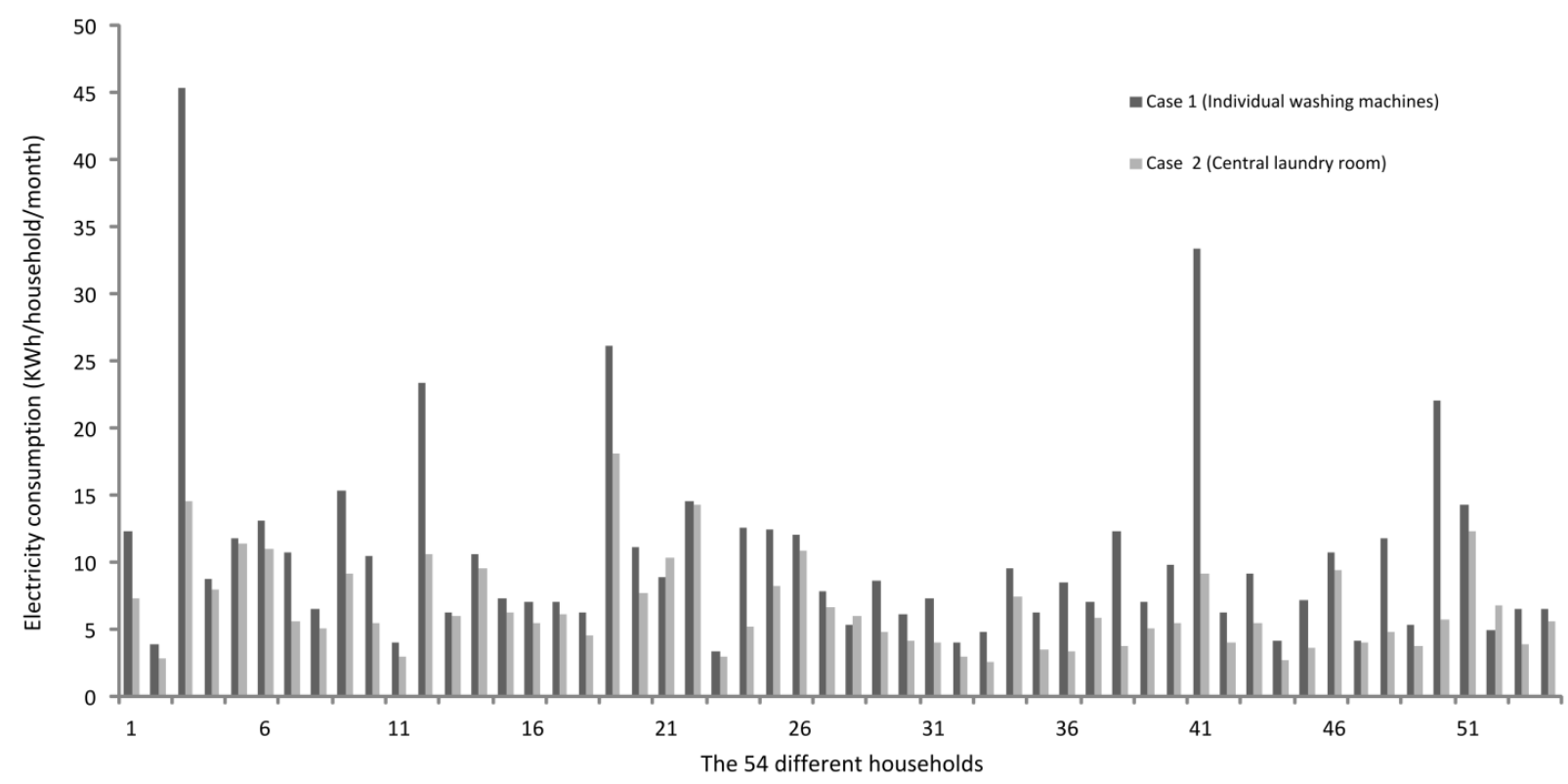

Figure 5: Comparison of electricity consumption for both design alternatives

\subsection{Adjusting Energy Performance Guarantees}

Energy performance contracts (guarantees) are becoming a powerful marketing offer by which contractors can attract more clients. These contracts can be signed either for a single building or a building stock, and may include energy-efficiency clauses related to the installation, operation and maintenance of energyconsuming systems $[6,47]$. Experts from our industrial partner confirm that a precise modeling approach, such as the one presented in this paper, would be very beneficial for adjusting energy performance thresholds to be defined in contract clauses. 
Zaraket T., Yannau B., Leray Y., Minel S., Chapatot E. (2015) 'An accupant-based energy consumption madel far user-facused design of residential buildings', Jaurnal of Mechanical Design, no. special issue on "User Needs and Preferences in Design Engineering", dai: 10.1115/1.4030202

\subsection{Offering and Improving Services}

Construction firms have started installing connected tools for the newly constructed green buildings [48]. The installation of these instruments is included in a global offer which also involves information and incitation services for building occupants. Such tools provide real-time information for occupants about their energy consumption levels, yet they do not provide detailed consumption data for all energy enduses. We believe that an 'activity-based visualization' of energy consumption might be more expressive and more incisive for occupants than nowadays traditionally 'sensor-based monitoring tools'. An 'activityallocation' model, which consists of assigning physical measuring sensors to a group of appliances belonging to a given activity, could thus be of great interest in this perspective. For instance, personal computer, game console and TV constitute the appliances of the 'entertainment' activity. The authors have already a published work on such a an activity/appliance allocation model in [49]. This concept is being studied now by our industrial partner and may be applied in the near future.

\section{DISCUSSION, CONCLUSIONS AND PERSPECTIVES}

This paper demonstrates how a user-focused model, which accounts for occupants' energy-related needs and activities, can be used within the engineering design, energy management processes, and marketing offers of residential buildings. An activity-based approach for modeling occupant-related energy consumption is presented and a sample of simulation results is demonstrated. The examples show how the model can be used to assess variability of energy consumption as a function of household profiles' heterogeneity. The possible integration of the proposed model into the industrial context of residential buildings is discussed, and a number of use-cases are identified. First, the model can be used in the design process of buildings: (1) as a complementary tool for energy simulation tools to produce more accurate energy estimates, and (2) to guide and better adapt certain design solutions. Second, the model can be used to better elaborate and finely tune energy performance contracts as a function of occupants' profiles. Third, the model can help improving the visualization features of energy monitoring tools through an activity-allocation decomposition of energy use. Some of the use-cases presented in this paper are still not completed, and are thus presented at an abstract level. The authors highlight that the ongoing work is focused on modeling the complete set of domestic activities, and the next step will be the development of a simulation tool which shall be implemented in the industrial context with our construction partner.

\section{ACKNOWLEDGMENTS}

The authors would like to thank the colleagues from BOUYGUES Construction who provided insight and expertise that greatly assisted the research presented in this paper.

\section{References}

[1] Saidur, R., Masjuki, H. H., and Jamaluddin, M. Y., 2007, "An application of energy and exergy analysis in residential sector of Malaysia," Energy Policy, 35(2), pp. 1050-1063.

[2] Masoso, O. T., and Grobler, L. J., 2010, "The dark side of occupants' behaviour on building energy use," Energy and Buildings, 42(2), pp. 173-177.

[3] Hoes, P., Hensen, J., Loomans, M., De Vries, B., and Bourgeois, D., 2009, "User behavior in whole building simulation," Energy and Buildings, 41(3), pp. 295-302.

[4] EPBD, 2014, "Concerted Action | Energy Performance of Buildings Directive" [Online]. Available: http://www.epbd-ca.eu/. [Accessed: 13-Sep-2014].

[5] Vierra, S., 2011, "Green Building Standards and Certification Systems | Whole Building Design Guide" [Online]. Available: http://www.wbdg.org/resources/gbs.php. [Accessed: 13-Sep-2014]. 
Zaraket T., Yannau B., Leray Y., Minel S., Chapatot E. (2015) 'An accupant-based energy consumption madel far user-facused design of residential buildings', Jaurnal of Mechanical Design, no. special issue on "User Needs and Preferences in Design Engineering", dai: 10.1115/1.4030202

[6] CPE, 2012, "Contrats de performance énergétique - Ministère du Développement durable" [Online]. Available: http://www.developpement-durable.gouv.fr/Contrats-deperformance,28987.html. [Accessed: 10-Feb-2014].

[7] Page, J., Robinson, D., Morel, N., and Scartezzini, J. L., 2008, "A generalised stochastic model for the simulation of occupant presence," Energy and Buildings, 40(2), pp. 83-98.

[8] Yu, Z., Fung, B. C. M., Haghighat, F., Yoshino, H., and Morofsky, E., 2011, "A systematic procedure to study the influence of occupant behavior on building energy consumption," Energy and Buildings, 43(6), pp. 1409-1417.

[9] Pachauri, S., 2004, "An analysis of cross-sectional variations in total household energy requirements in India using micro survey data," Energy policy, 32(15), pp. 1723-1735.

[10] Fabi, V., Andersen, R., Corgnati, S., and Olesen, B., 2012, “Occupants' window opening behaviour: A literature review of factors influencing occupant behaviour and models," Building and Environment, 58, pp. 188-198.

[11] Swan, L. G., and Ugursal, V. I., 2009, "Modeling of end-use energy consumption in the residential sector: A review of modeling techniques," Renewable and Sustainable Energy Reviews, 13(8), pp. 1819-1835.

[12] Clevenger, and Haymaker, 2006, "The impact of the building occupant on energy modeling simulations," Joint International Conference on Computing and Decision Making in Civil and Building Engineering, Montreal, Canada, pp. 1-10.

[13] Seryak, J., and Kissock, K., 2003, "Occupancy and behavioral affects on residential energy use," Proceedings of the Solar Conference, pp. 717-722.

[14] Emery, A. F., and Kippenhan, C. J., 2006, "A long term study of residential home heating consumption and the effect of occupant behavior on homes in the Pacific Northwest constructed according to improved thermal standards," Energy, 31(5), pp. 677-693.

[15] Malavazos, C., Tzovaras, D., Kehagias, D., and loannidis, D., 2011, "Energy and behavioural modelling and simulation for ee-buildings design," Proceedings of the CIB W78-W102 2011: International Conference, Sophia Antipolis, France.

[16] Kashif, A., Ploix, S., Dugdale, J., and Binh Le, X. H., 2013, "Simulating the dynamics of occupant behaviour for power management in residential buildings," Energy and Buildings, Volume 56, pp. 85-93.

[17] Bourgeois, D., Reinhart, C., and Macdonald, I., 2006, "Adding advanced behavioural models in whole building energy simulation: a study on the total energy impact of manual and automated lighting control," Energy and buildings, 38(7), pp. 814-823.

[18] Chiou, Y.-S., 2009, "Deriving US household energy consumption profiles from american time use survey data a bootstrap approach," 11th International Building Performance Simulation Association Conference and Exhibition, Glasgow, Scotland, pp. 151-158.

[19] Zaraket, T., 2014, "Stochastic Activity-based Approach of Occupant-related Energy Consumption in Residential Buildings," Doctoral Dissertation, Ecole Centrale Paris.

[20] Ellegård, K., and Palm, J., 2011, "Visualizing energy consumption activities as a tool for making everyday life more sustainable," Applied Energy, 88(5), pp. 1920-1926.

[21] Pennavaire, C., 2010, "Comprehensive modeling of energy use in households. An Agent Based case study on potential behavioural and technicalmeasures towards an energy neutral urban environment.," Master of Science in Construction Management and Engineering, University of technology, Eindhoven. 
Zaraket T., Yannau B., Leray Y., Minel S., Chapatot E. (2015) 'An accupant-based energy consumption madel far user-facused design of residential buildings', Jaurnal of Mechanical Design, no. special issue on "User Needs and Preferences in Design Engineering", dai: 10.1115/1.4030202

[22] Kashif, A., Ploix, S., Dugdale, J., and Le, X. H. B., 2011, "Agent based framework to simulate inhabitants' behaviour in domestic settings for energy management," 3rd International Conference on Agents and Artificial Intelligence (ICAART 2011), Rome.

[23] Swan, and Ugursal, 2009, "Modeling of end-use energy consumption in the residential sector: A review of modeling techniques," Renewable and Sustainable Energy Reviews, 13(8), pp. 18191835.

[24] Yao, R., and Steemers, K., 2005, "A method of formulating energy load profile for domestic buildings in the UK," Energy and Buildings, 37(6), pp. 663-671.

[25] Yun, G. Y., and Steemers, K., 2011, "Behavioural, physical and socio-economic factors in household cooling energy consumption," Applied Energy, 88(6), pp. 2191-2200.

[26] Robinson, D., 2006, "Some trends and research needs in energy and comfort prediction," Windsor Conference.

[27] Paauw, J., Roossien, B., Aries, M. B. C., and Santin, O. G., 2009, "Energy Pattern Generator; Understanding the effect of user behaviour on energy systems," 1st European conference energy efficiency and behaviour, pp. 9-10.

[28] Weber, C., and Perrels, A., 2000, "Modelling lifestyle effects on energy demand and related emissions," Energy Policy, 28(8), pp. 549-566.

[29] Mansouri, I., Newborough, M., and Probert, D., 1996, "Energy consumption in UK households: Impact of domestic electrical appliances," Applied Energy, 54(3), pp. 211-285.

[30] Lutzenhiser, L., and Bender, S., 2008, "The 'Average American' Unmasked: Social Structure and Differences in Household Energy Use and Carbon Emissions."

[31] Guerin, D. A., Yust, B. L., and Coopet, J. G., 2000, "Occupant predictors of household energy behavior and consumption change as found in energy studies since 1975," Family and Consumer Sciences Research Journal, pp. 48-80.

[32] Nugroho, S. B., Fujiwara, A., Zhang, J., Kanemoto, K., Moersidik, S. S., and Abbas, S., 2010, "DEVELOPMENT OF A HOUSEHOLD ENERGY CONSUMPTION MODEL FOR MEGACITIES IN ASIA," Hong Kong.

[33] Yun, G. Y., Tuohy, P., and Steemers, K., 2009, "Thermal performance of a naturally ventilated building using a combined algorithm of probabilistic occupant behaviour and deterministic heat and mass balance models," Energy and buildings, 41(5), pp. 489-499.

[34] McLoughlin, F., Duffy, A., and Conlon, M., 2012, "Characterising domestic electricity consumption patterns by dwelling and occupant socio-economic variables: An Irish case study," Energy and Buildings, 48, pp. 240-248.

[35] Yohanis, Y. G., Mondol, J. D., Wright, A., and Norton, B., 2008, "Real-life energy use in the UK: How occupancy and dwelling characteristics affect domestic electricity use," Energy and Buildings, 40(6), pp. 1053-1059.

[36] Tanimoto, J., Hagishima, A., and Sagara, H., 2008, "Validation of probabilistic methodology for generating actual inhabitants' behavior schedules for accurate prediction of maximum energy requirements," Energy and Buildings, 40(3), pp. 316-322.

[37] Richardson, I., Thomson, M., Infield, D., and Delahunty, A., 2009, "Domestic lighting: A highresolution energy demand model," Energy and Buildings, 41(7), pp. 781-789.

[38] Richardson, Murray Thomson, David Infield, and Conor Clifford, 2010, "Domestic electricity use: A high-resolution energy demand model," Energy and Buildings, 42(10), pp. 1878-1887.

[39] Widén, J., and Wäckelgård, E., 2010, "A high-resolution stochastic model of domestic activity patterns and electricity demand," Applied Energy, 87(6), pp. 1880-1892. 
Zaraket T., Yannau B., Leray Y., Minel S., Chapatot E. (2015) 'An accupant-based energy consumption madel far user-facused design of residential buildings', Journal of Mechanical Design, no. special issue on "User Needs and Preferences in Design Engineering", dai: 10.1115/1.4030202

[40] Muratori, M., 2013, "A Highly Resolved Modeling Technique to Simulate Residential Power demand," Applied Energy, 107, pp. 465-473.

[41] Subbiah, R., 2013, "An Activity-Based Energy Demand Modeling Framework for Buildings: A Bottom-Up Approach," Virginia Polytechnic Institute and State University.

[42] Kashif, A., Ploix, S., Dugdale, J., and Binh Le, X. H., 2012, "Simulating the dynamics of occupant behaviour for power management in residential buildings," Energy and Buildings.

[43] Quijano, J., Herpson, C., and Sabouret, N., 2010, "Prédiction de l'activité humaine afin de réduire la consommation électrique de l'habitat," pp. 43-52.

[44] Zaraket, T., Yannou, B., Leroy, Y., Minel, S., and Chapotot, E., 2013, "A usage model-driven approach for forecasting occupant-related energy consumption in residential buildings," Proceedings of CONFERE 2013, Biarritz, France.

[45] Zaraket, T., Yannou, B., Leroy, Y., Minel, S., and Chapotot, E., 2014, "A Stochastic activity-based approach for forecasting occupant-related energy consumption in residential buildings," Proceedings of International Design Engineering Technical Conferences (IDETC), American Society of Mechanical Engineering, Buffalo, N.Y, USA.

[46] ENERTECH, 2008, "Residential Monitoring to Decrease Energy Use and Carbon Emissions in Europe" [Online]. Available: http://remodece.isr.uc.pt/.

[47] Website, 2014, "Le site des contrats de performance énergétique" [Online]. Available: http://www.lecpe.fr/. [Accessed: 11-Dec-2014].

[48] Lemoniteur, 2011, "Energy Pass, nouvel outil de maîtrise des charges dans les bâtiments neufs," lemoniteur.fr [Online]. Available: http://www.lemoniteur.fr/145logement/article/actualite/860961-energy-pass-nouvel-outil-de-maitrise-des-charges-dans-lesbatiments-neufs. [Accessed: 19-Jan-2014].

[49] Picon, L., Yannou, B., Zaraket, T., Minel, S., Bertoluci, G., Cluzel, F., and Farel, R., 2013, "Use-phase memory: A tool for the sustainable construction and renovation of residential buildings," Automation in Construction, 36, pp. 53-70. 